\title{
Request Expressions in Japanese Language for Educational Purpose
}

\author{
Ely Triasih Rahayu*, Hartati, Anggita Stovia \\ Faculty of Humanities, Jenderal Soedirman University, Indonesia
}

Received August 19, 2019; Revised December 5, 2019; Accepted December 17, 2019

\begin{abstract}
Copyright $\bigcirc 2020$ by authors, all rights reserved. Authors agree that this article remains permanently open access under
\end{abstract} the terms of the Creative Commons Attribution License 4.0 International License

\begin{abstract}
This research analyzes request expressions in Japanese language in correlation with situational factor. Situational factor may be related to age, position and closeness level factors. The request expressions analyzed are conversations in the context of services, about how a request expression is said by a speaker (the one to give service) to hearer (the one to receive service). The objective of a request expression is to persuade the hearer to do what the speaker instructs. If the request language used does not comfort the hearer, it is likely that the objective of a request expression is not communicated.
\end{abstract}

Keywords Request Expression, Japanese Language, Speaker, Hearer, Service, Language

\section{Introduction}

Language is, with regard to its function as a means to communicate with others, highly required in humans' social life. Language is correlated with the society that speaks it and with humans as a social being that highly needs it. Yuwono (2005:3) states that language is a sound mark system agreed on to be used by members of certain society group in their cooperation, communication and self-identification.

Japanese language has linguistic levels, so using it requires considering many factors, such as social status and context existing in a situation. It is necessary to recognize whether such expressions are generally used by men or women, children or adults, and what relation to correlate them (Edizal, 2010:1). Polite language variety usage is also taken into consideration in Japanese language, in which polite language is used to show respect for an interlocutor, while common language is used in a more informal situation and for a close interlocutor.

Moreover, Suwito (1985:30) explains that using language or communicating using language is an event of verbal interaction which involves some elements, such as speaker, hearer (receiver), topic, setting and situation scene (situation of the place where a speech is made). In language usage, every speaker will always take account of who he/she is talking to, where he/she speaks, speech content and what situation a speech is made in.

From the explanation above, we may conclude that language serves the main role in a person's communication. Language is a system of arbitrary sound symbols used by members of a community in their cooperation, interaction and self-identification (Kridalaksana, 2001: 21). Language is born in an area and merges with people's customs in the area. This shows that language and language usage should always be correlated with society's social activities.

Language usage as a social indication is not only determined by linguistic factors, but also by non-linguistic factors in the form of social factors. Social factors are highly influenced by society's social condition, including social status, level of education, age, economic level, sex and other social factors, in conformance to Kabaya's opinion (2009:77):

コミュニケーションをする時に、コミュニケーシ ヨン主体（話し手,書き手, 聞き手, 読み手) が（場 面(人間関係, 場))のことを考える。Komunikeeshon o suru toki ni, komunikeeshon shutai (hanashite, kakite, kikite, yomite) ga (bamen (ningenkankei,ba)) no koto o kangaeru.

When communicating, a communicator (speaker, writer, listener, reader) should take account of background (of relationship between communicators and place where communication is performed).

The examples below are greeting expressions (good morning) in Japanese language in variations:

- Ossu

- Ohayou

- Ohayougozaimasu

It is inappropriate for a student to say Ossu to his/her teacher. Ossu may be said to close peers. It is more 
appropriate for a student to say greeting expression ohayou gozaimasu to his/her teacher and the teacher may reply with ohayou. In Indonesian language, ossu is translated to yes, ohayou morning, and ohayou gozaimasu good morning. Similarly, in the apology expression below:

- Gomen

- Gomenasai

- Moushiwakegozaimasen/Moushiwakearimasen

The longer an expression, the more polite it is felt. In the three expressions above, moushiwakegozaimasen/ moushiwakearimasen is more polite than the other two expressions. Gomen is an apology between friends or close people, gomenasai is a more polite apology than gomen which is said to a person older than speaker, while the expression moushiwakegozaimasen/ moushiwakearimasen is used when a person feels deeply guilty about a person whose position is above that of speaker, for example towards speaker's leader, teacher or senior.

Request expression is an expression related to imperative sentence. Request expression in Japanese language is called irai hyougen. In an event of service communication, a speaker uses his/her language to provide consumer service. A speaker should proficiently arrange his/her language so that the content of his/her sentence in the form of request expression as well as imperative sentence is acceptable to the hearer, especially when the hearer is a person whose position is higher than that of the speaker, then the request expression should be in polite language. The objective of a request expression is to persuade the hearer to do what the speaker instructs. If a request language does not comfort the hearer, the objective of a request expression may not be communicated.

This research analyzes request expressions in Japanese language in correlation with situational factor. Situational factor may be related to age, position and closeness level factors. The request expressions to be analyzed are conversations in the context of services, about how a request expression is said by a speaker (the one to give service) to hearer (the one to receive service). It is explained above that a request expression is an imperative sentence intended for the hearer to respond.

\section{Sociolinguistics}

There are factors that influence language usage in the society. The science to learn about factors existing in the society is sociolinguistics. Soeparno (2002:25) argues that "sociolinguistics is a linguistic sub-discipline to learn about language in relation to social factors." Sociolinguistics is a science to learn about factors existing in language speakers' society, for example in Japanese language. Japanese people considerably pay attention to their language. Considering sociolinguistic aspects, any problems arising from inappropriate language usage in social context may be reduced or even eliminated.
Understanding sociolinguistic principles, a person will highly consider choosing language variations pursuant to social context besides accuracy of morphology in his/her verbal interaction. If speakers understand this, communication in society will conform to prevailing norms.

Sociolinguistics studies about the relation between language and society by correlating two fields which may be studied separately, namely language formal structure by linguistics and society structure by sociology (Wardhaugh, 1986; Holmes, 1992; Hudson, 1996). Studying language from the perspective of sociolinguistics, such study will correlate language/speech conduct with social status (Dittmar 1976: 27).

Language study may be conducted internally or externally. Internal study means a study based on theories or procedures existing in linguistics, such as language internal structure. The said language internal structure is phonological, morphological or syntactical structure. External study means a study based on language external factors in relation to language usage and language speaker within social groups. External study, besides using theories and procedures in linguistics, also uses theories and procedures of other disciplines, such as sociological, psychological and anthropological disciplines.

External study employs two or more scientific disciplines, such as sociolinguistics, which is combination of sociology and linguistics; psycholinguistics, which is combination of psychology and linguistics; anthropolinguistics, which is combination of anthropology and linguistics; and neurolinguistics, which is combination of neurology and linguistics. Internal study is called microlinguistic study, while external study is called macrolinguistic study (Chaer, 2004:2).

Language is social institution. This social form generates language varieties which do not only serve to be a hint of difference in speaker's social group, but also serve to be an indication of linguistic situation and reflect the objectives, topics, rules and modes of language usage (Nababan, 1991:2). Language study, from the perspective of social form as explained above, is the definition of sociolinguistics.

As discussed above, sociolinguistics is a term consisting of two word elements; socio- and linguistics. Linguistics is a science to learn about the nature of language and linguistic characteristics. Linguistic characteristics include linguistic elements in the form of phoneme, morpheme, word, sentence and relation between the elements (sentence structure). The word socio- may be defined as social, which is anything related to society. Based on such explanation, it is clear that sociolinguistics considers or puts language position in its relationship with language user in non-homogenous society (Hudson, 1980; Wardaught, 1986; Holmes, 1992; Wijana, 2006; Jendra, 2010)

Sociolinguistics takes language as a means of human 
communication in social life, since in their social life humans do not serve to be individual anymore, but social community. This means that sociolinguistics considers language first to be a social system, communication system, and part of certain community and culture (Suwito, 1985:2).

\section{Language Choice}

Communication will run well if its participants are aware of and understand their position in performing speech. Inappropriate or incorrect language usage will result in awkward, inappropriate communication and discomfort its communicators. On the contrary, if communicators make language choice appropriately, communication will run smoothly. Language choice takes place because of social, cultural and situational influences existing in such community (Suwito, 1987).

In a multilingual society, language choice is actually something normal, since it occurs with every speech event which engages speech participants. Speech participants refer to speaker, hearer, and person talked to. The reason is that social phenomena are dynamic, constantly moving and changing and affect social structure and language usage (Gumperz, 1982; Fasold, 1984).

Verbal interaction in language communication within which language choice accuracy is required is also closely related to speech components. Speech components may reflect its speech community. The said speech community is a collection of speakers with the same language based on the same norms in using such language (Fishman, 1972; Suwito, 1983).

Speech components are proposed by Hymes (1973) with his renowned acronym SPEAKING (scene/setting background, participants speech participants, ends speech objective, act sequence speech topic, key speech tone, instrumentalities tool/means, norms speech norms and genres type of speech).

Speech scene is the place where speech act is performed. Language choice in a speech will certainly adapt to the place of speech such as office, school, beach, family and market, while speech situation refers to the situation in which a speech is performed. Speech situation may be formal or informal. Language choice with formal speech is certainly necessary when a person is talking to his/her superior at office. On the contrary, it will be strange in a situation of gathering in a reunion event.

Speech participants refer to speaker, hearer and the person whom is talked to. Language choice among speech participants is determined with difference in vertical dimension and horizontal dimension. The first dimension includes difference in age, socioeconomic status and position in the community. A speaker should make appropriate language choice when he/she is talking to a hearer whose position is higher than that of the speaker.
The second difference in dimension includes, among others, difference in the level of closeness between speech participants.

Speech objective is the objective of a speech communicated by a speaker. This is also correlated with the expectation after massage content is communicated by speaker. Speech topic is communicated by a hearer either individually or socially. Changes in speech topic may sometimes occur sequentially in a speech act. Speech topic in speech event will influence language choice.

Speech tone refers to verbal speech and nonverbal act. Speech tone may be in the form of change in language sound. With a change in sound, language may give a hint that a person is currently happy, sad, dissatisfied, serious, etc. Nonverbal speech tone may be in the form of limb movement, change in countenance and look in the eye. A person's head nodding or wink may indicate that such person agrees even if not expressed verbally.

Means of speech refers to speech medium. Means of speech may be oral, writing and gesture. An example of oral means is using telephone, of written means is using facsimile, and of gesture is using flag semaphore.

Speech norms are related to norms in communication. Norms regulate whether something is allowed/not allowed to be used by speech participants during a speech. A person may be stated as impolite during speech when he/she do not comply with communication norms. In Japanese speech community, a person will be deemed impolite if he/she ask about something personal, for example age, number of children, marital status, etc.

Type of speech is a speech which may be distinguished by form, for example, pantun, poem, story and drama script.

Poedjosudarmo (1979) has also explained thirteen speech components adapted to linguistic situation in Indonesia, especially in Java. The thirteen speech components are: (1) speaker's personality, (2) colors of emotion, (3) speech intention, (4) speaker's assumption about hearer, (5) third person presence, (6) tones and situation of speech, (7) speech scene, (8) topic, (9) speech medium, (10) speech order, (11) conversation ecology, (12) discourse form, and (13) other linguistic norm.

Comparing the opinion of Poedjosudarmo (1979) and Hymes (1973), it is found that Poedjosudarmo emphasizes more in speech participant aspect. This is shown with some components of speech participant aspect expressed in sequence, which are speaker's personality, colors of emotion, speech intention, assumption about hearer and third person presence, while Hymes (1973) emphasizes speech scene more, which is a component that considerably affects the form of speech.

Hymes (1973) assumes speech topic to be the center of speech act, while Poedjosudarmo (1979) assumes speech topic only to be one point of speech components of which role is considerably influenced by other speech components. Poedjosudarma (1979) includes speech scene 
as one of speech components, which is, by Hymes, excluded from speech components together with speech situation.

Leech (1993) illustrates language choice made by Kalala tribe that lives in Bukavu, in the South of Zaire, a city in Africa. Zaire is a city to which many people come for work and business, so that Zaire is a city of heterogeneous, multicultural and multilingual society. Therefore, there are many people in this city with different languages.

Kalala tribesmen speak different languages based on place where speech act is performed. When Kalala tribesmen communicate with their own family, they will speak Shi language in informal variety. Kalala tribesmen speak Shi language in formal variety in a party. In communication with people of other ethnic, Kalala tribesmen speak Swahili national language. Zairean Swahili language is spoken in communication with government officers or during job application. In communication with younger people, such as children, Kalala tribesmen speak Kingwana language. Slang or Indoubil language is spoken in a conversation with peers or close friends.

A student's language choice for his/her teacher should differ from his/her language choice for his/her friends. Similarly, speech between subordinate and superior or between shop keeper and customer should differ.

Language used in family communication with family members as participants will have topic regarding family activities. Below is a table of topics pursuant to domains of language usage.

Table 1. Domains of Language Usage

\begin{tabular}{|c|c|c|c|}
\hline Domain & Participant & Place & Topic \\
\hline Family & $\begin{array}{c}\text { Parents, } \\
\text { children }\end{array}$ & Home & Family event plan \\
\hline Friendship & Friends & Beach & $\begin{array}{c}\text { How to play beach } \\
\text { volleyball }\end{array}$ \\
\hline Religion & Pastors & Church & $\begin{array}{c}\text { Sunday worship } \\
\text { choice }\end{array}$ \\
\hline Education & $\begin{array}{c}\text { Teachers, } \\
\text { students }\end{array}$ & School & Mathematics subject \\
\hline Office & Employees & Workplace & Promotion proposal \\
\hline
\end{tabular}

Source: Fishman (1972: 22)

\section{Language Variation}

Language usage in the community is determined by linguistic and nonlinguistic factors. According to Poedjosoedarmo (1976:2), language variations are forms or variants of language, each of which has patterns equal to its parent language's general pattern.

Dwiraharjo (1997:59) in this case argues that manifestation of language variations comprises idiolect, dialect, language variety, register and speech level. The manifestation of language variations is briefly explained by Dwiraharjo (1997:59-60) as follows:

- Idiolect is individual language variation, which means that the typical characteristics of a person's speech differ from those of others.

- Dialect is language variation which is determined by difference in speaker's place of origin and difference in speaker's social class. Therefore, there are geographic dialects and social dialects or sociolects.

- $\quad$ Language variety is language variation as the result of difference in speaker's standpoint, place, topic and situation. Language variety comprises formal and informal language varieties.

- $\quad$ Register is language variation resulted from typical characteristics of users' necessity, for example advertising language, heading language, speech language, etc.

- Speech level is language variation which is determined by difference in speaker's assumption about relationship with hearer. For example, in Javanese language there are ngoko, madya, and krama speech levels. In Japanese language, there are futsuugo and keigo forms.

\section{Research Method}

Based on the problems, this research focuses on request expressions in service communication. Service communication is a process of communication in which language is used to give others service. In this research, communication which is taken as the source of data is communication at office, tourist attraction and hotel. The respondents are tour guides, shop keepers and hotel receptionists. This qualitative descriptive research reveals and describes various existing phenomena in the use of request expressions in narration form which is studied thoroughly.

This qualitative descriptive research employs explanative dimension by viewing the language studied not a sich on what is viewed, but it tries to explain why the object observed has such fact. This research also explains the cause and effect (reason-objective) of why such object seems as it is and how a request expression is arranged under linguistic and nonlinguistic rules. The linguistic data are in the form of any linguistic phenomena which are pursuant to certain aspects studied (Subroto, 1992:34). The said nonlinguistic data are situational factor.

The problems have been determined in the proposal before field work, and the type of research strategy is embedded case study research (Sutopo, 2006:227).

Principally, this research employs tape recording, listening and recording technique. Recording technique is employed to collect data by spontaneously tape recording oral language usage (Subroto, 1992:36). In this case, a tape recorder is used to record existing conversation naturally.

Using listening and recording techniques, the research 
listens to spontaneous oral language usage and records relevant data in line with the aims and objectives of this research (Subroto, 1992:42). These relevant data are recorded along with its setting context.

\section{Discussion}

In Japanese language, irai hyougen or request expression has many language variations pursuant to situational factor. Japanese speakers have a linguistic norm, especially for business purpose, that language is expressed aiming at elevating hearer's position. In service domain, a speaker uses his/her language choice to give customer service even if the speech content is giving the hearer instruction. The pattern of sentence Go-+ kudasai is a respectful language. The communication is made via email. An employee of an eyelashes company reports on his/her work to his/her supervisor.

1) 生産 難易度 ランクを添付ファイルょりご確 認ください。

seisan nani do ranku o tenpu fairu yori gokakunin kudasai.

Please check the attached file of the difficulty level of eyelashes production.

2) 中間の闌に集計 結果がありますのでご参 照ください。

Chuukan no ran ni shuukei kekka ga arimasu node gosanshou kudasai.

Please take as reference the total number written in the middle column.

The two imperative/request sentences above are of the sonkeigo form (respectful language), used by an employee to show respect for his/her supervisor. The marker of sonkeigo form is the usage of prefix go- in front of noun (gokakunin and gosanshou), while the request form is marked with the word kudasai. Gokakunin kudasai and gosanshou kudasai are written by the employee as a request expression for the supervisor to check and take as reference in the eyelashes working. Below is an example of request expression with the same pattern but different prefix, still used by the same employee to his/her supervisor.

3) 不明な点があればお知らせください。

Fumei na ten ga areba oshirase kudasai.

Please inform (me) in case of anything unclear.

Sentence 3) is also a request expression of sonkeigo form. Different from sentences 1) and 2), sentence 3) uses prefix $o$ - as a marker of respectful language form. This may be analyzed based on how to read kanji letters. Kanji in the word sonkeigo of sentences 1) and 2); kakunin and sanshou is kanji kango (kanji with Chinese reading method), so that prefix go- should be affixed. Kanji in the word sonkeigo of sentence 3) shiraseru is kanji wago (kanji with Japanese pure reading method) so that prefix $o$ - should be affixed.
This provision does not only apply for verb, but also for noun and adjective.

The marker of request expression of Go /O + kudasai is used based on the factor of difference in position. The formality level is viewed from the domain and communication media. The domain used is office and the communication media is e-mail, so that the request expression is made formally. This may be viewed from the employee's language choice.

The following conversation between a passenger and a taxi driver also shows a formal request expression, as shown with the use of pattern (verb) te + kudasai.

4) Passenger：すみません、あの信号を右へ曲がっ てください。

Sumimasen, ano shingou wo migihe magatte kudasai Sorry, please turn right at the traffic mark.

Taxi Driver：右ですね。

Migidesune

It's right

Passenger : ええ。

ee

yes.

In the data above, the passenger instructs the taxi driver to turn the car to the right. The passenger, even if he/she is the one to pay the taxi driver, still makes a formal form of request. The verb magaru changes to the verb form $\sim$ te (to magatte) and is followed by the word kudasai as a marker of request/imperative sentence. The passenger makes formal language choice since the conversation is performed in their first encounter. The age factor also serves to be the determinant, that the passenger is about 20 years old while the taxi driver is about 50 years old.

$\sim T e$ kudasai is a neutral form of request. It means that the expression may be spoken to the hearer at any condition both to young and older people, superior/submissive, people with close or not close relationship. The examples of more polite request expressions than the form $\sim t e$ kudasai are as follows:

5) Superior: それではデザインつけま 2 型は、

Soredewa desain tsukema ni kata wa,

16 日に出荷お願いします。

16 nichi shukka onegaishimasu.

please, deliver it on 16

'please deliver 2 models of (artificial) eye lids on 16.' submissive: はい、わかりました。

Hai, wakarimashita

Understood

'undertood'

The use onegaishimasu 'please' is a request expression which is more polite than the use of expression kudasai. In Japanese language, onegaishimasu is a linguistic marker of kenjougo. Kenjougo is a linguistic marker used to respect others by lowering the speaker's position (humble language). Onegaishimasu used in the above expressions is followed by the word shukka 'delivery', yet the sentence 
subject is in the form of noun tsukema ni, the word '2 models of (artificial) eye lids' refers to shukka that the word is considered as a passive participle verb of 'sent'. Thus, the word shukka onegaishimasu means "please send" which is considered as a polite request using the onegaishmasu marker.

The researcher finds the data showing request expression of older request maker. The conversation happens in tourism domain between a tourist and a tour guide.

6) Tour guide : ヌサ デゥア行きのシャトルバス はもう出発しまし

たので、次のスケジュールは午後 2 時にここか らです。

Nusa Dua iki no shattoru basu wa mou shuppatsu shimashitanode, tsugi no sukejuuru wa gogo 2 ji ni koko kara desu.

The shuttle bus to Nusa Dua has departed. The next schedule will be at $2 \mathrm{pm}$ from here.

Tourist: じゃあ、入れてもらっていい？

Jaa, irete moratte ii?

If so, please book for me?

In the conversation above, the tourist uses the verb form $\sim t e$ in the request expression iretemoratteii? In Japanese language, the usage of verb te is a mark of informal imperative sentence. The instructive expression is used by the tourist since he/she has the right to the tour guide's service, so that the language is not necessarily formal. On the other hand, the age factor also influences the formality of expression made.

\section{Conclusions}

Sociolinguistics views language as a social system, communication system and part of certain community and culture. Language usage is a form of social interaction existing in concrete situations in a community. Learning language in sociolinguistic context means learning language from sociocultural context and its usage situation, so that we learn language from the perspective of its speaker and listener. The nature of language is a process of verbal interaction between its speaker and listener. This verbal interaction process highly takes who is talked to, where, when, about what and in what situation into consideration. It is here that sociolinguistics serves significant role.

Request expression is an expression related to imperative sentence. Request expression in Japanese language is called irai hyougen. In an event of service communication, a speaker uses his/her language to provide consumer service. A speaker should proficiently arrange his/her language so that the content of his/her sentence in the form of request expression as well as imperative sentence is acceptable to the hearer, especially when the hearer is a person whose position is higher than that of the speaker, then the request expression should be in polite language. The objective of a request expression is to persuade the hearer to do what the speaker instructs. If a request language does not comfort the hearer, the objective of a request expression may not be communicated.

\section{REFERENCES}

[1] Chaer, Abdul. (2004). Tata Bahasa Praktis Bahasa Indonesia. Jakarta: Rineka Cipta.

[2] Dittmar, Norbert. (1976). Sociolinguistics: A Critical Survey of Theory and Application. London: Edward Arnold.

[3] Dwiraharjo, M., (1997). 'Fungsi dan Bentuk Krama dalam Masyarakat Tutur Jawa Studi Kasus di Kotamadya Surakarta. Surakarta: UNS.

[4] Edizal, (2010). Tutur Kata Manusia Jepang. Padang: Kayupasak.

[5] Fasold, R. (1984). The Sociolinguistics of Society. Oxford: Basil Blackwell.

[6] Fishman, J.A. (1972). Language and Sociocultural Change. California: Academic Press.

[7] Gumperz, J.J. (1982). Language and Social Identity. London: Cambridge University Press.

[8] Holmes, Janet. (1992). An Introduction to Sociolinguistics. London: Longman.

[9] Hudson, R.A. (1996). Sociolinguistics. Cambrige: Cambrige University Press.

[10] Hymes, Dell. (1973). Foundations in Sociolinguistics: An Ethnographic Approach. Philadelphia: University of Pennsylvania Press.

[11] Kridalaksana, Harimurti. (2001). Kamus Linguistik. Jakarta: Gramedia Pustaka Utama.

[12] Leech, Geoffrey. (1993). Prinsip-prinsip Pragmatik. Jakarta: Penerbit Universitas Indonesia (UI-Press).

[13] Nababan, P.W.J. (1991). Sosiolinguistik Suatu Pengantar. Jakarta: PT Gramedia Pustaka Utama.

[14] Poedjosoedarmo, Soepomo. (1976). Kode dan Alih Kode. Yogyakarta: Balai Penelitian Bahasa.

[15] Poedjasoedarma, Soepomo. 1979. Tingkat Tutur Bahasa Jawa. Jakarta: Depdikbud. Jurnal Pendidikan Bahasa dan Sastra ISSN: 1693-623X Vol 1, No 1, 2013 (hal 97-107) http://jurnal.pasca.uns.ac.id

[16] Soeparno. (2002). Dasar-dasar Linguistik Umum. Yogyakarta: PT Tiara Wacana.

[17] Subroto. (1992). Penelitian Kualitatif. Jakarta: Raja Grafindo Persada.

[18] Sutopo. (2006). Metodologi Penelitian Kualitatif. Surakarta: UNS.

[19] Suwito. (1983). Pengantar Awal Sosiolinguistik Teori dan 
Problema. Surakarta UNS Press.

[20] Suwito. (1985). Pengantar awal sosiolinguistik: teori dan problema. Surakarta: henary offset.

[21] Wardhaugh, Ronald. (1986). An Introduction to Sociolinguistics. Oxford: Basil Blackwell.

[22] Wijana, I Dewa Putu. (2006). Sosiolinguistik. Yogyakarta: Pustaka Pelajar.

[23] Yuwono, Untung. (2005). Pesona bahasa. Jakarta: PT Gramedia Pustaka Utama. 